\title{
CAUSES FOR CULLING FIRST CALVING COWS ON FARMS WITH DIFFERENT LEVELS OF PRODUCTION
}

\author{
P. Stojić ${ }^{1}$, R. Beskorovajni ${ }^{1}$, V. Pantelić ${ }^{2}, \check{Z}$. Novaković ${ }^{2}$, S. Bojković \\ Kovačević ${ }^{3}$, D. Stanojević ${ }^{4}$
}

${ }^{1}$ Institute PKB Agroekonomik, Zrenjaninski put bb, 11213 Padinska Skela, Republic of Serbia
2 Institute for Animal Husbandry, Autoput 16, P.Box 23, 11080 Zemun, Republic of Serbia
${ }^{3}$ PKB Center for Cattle Production, Zrenjaninski put bb, 11213 Padinska Skela, Republic of Serbia
${ }^{4}$ Faculty of Agriculture, Nemanjina 6, 11080 Zemun-Belgrade, Republic of Serbia
Corresponding author: pStojić@sezampro.rs
Original scientific paper

\begin{abstract}
It is general knowledge that management influences results in cattle production to the highest extent, and that the culling of cows is a very good indicator of the success of farm management. A comparison of results of culling for first calving cows on farms with various levels of production in 2011 established differences both for the number of culled animals and the reasons for culling. On farms with higher levels of production, the share of first calving cows in overall culling was $25.9 \%$ or $4.5 \%$ less than on farms with a lower level of production, i.e. $4.8 \%$ less died, and $0.7 \%$ first calving cows had to be slaughtered, while 5.6\% more first calving cows were culled for economic reasons. At both levels of production, dominant reasons for culling were diseases of the legs and hoofs, which can be linked to the tie stall system (more pronounced on farms with higher production) and metabolic disorders (more dominant on farms with lower production). Reproduction was a more considerable problem on farms with higher milk production, while culling due to selection was more pronounced on farms with lower production. In early lactation of first calving cows, regardless of the level of production, dominant reasons for culling on farms are leg and hoof problems and metabolic disorders (total: $55 \%$ i.e. $55.9 \%$ ). When reasons for culling of first calving cows after 100 days of lactation are investigated, on farms with high production the significance of diseases of legs and hoofs remains almost unchanged, but culling due to reproduction grows to $28 \%$. On farms with lower production, culling due to leg and hoof diseases is considerably reduced after 100 days of lactation, however culling due to selection is tripled (62\%).
\end{abstract}

Key words: Holstein, first calving cows, level of production, culling 


\section{Introduction}

Under conditions of high milk production, management strives to decrease differences between cows in the herds, i.e. to homogenize the herd as much as possible. This is most often realized by applying a comprehensive rearing technology, using quality genetics and planned culling, which contributes to selection efficiency by a more reliable evaluation of heritability (Djedović et al., 2002 and Stojić et al., 2000).

As for the culling cows, depending on the level of production, dominant reasons for culling also change. According to research by numerous authors, total culling, including also deaths, is 32-36\% (Stojić et al., 2012; Chiumia, 2011; Pinedo et al., 2010; Seegers et al., 1998 and Dürr, 1997), while Maher et al., (2008) established total culling at a level of $21.3 \%$. In high producing herds, according to research by Nienartowicz-Zdrojewska et al., (2009), cows were most frequently culled because of problems with reproduction, mastitis and leg and hoof diseases. The relationship between low production, metabolic disorders and low reproductive efficiency was noted by Beaudeau et al., (2000). However, relevant to the free and tie stall system, Beaudeau et al., (1993), established that the rearing system influences culling caused by mastitis and distortions, but not culling caused by metabolic disorders or diseases of the locomotion apparatus.

By analyzing culling in Quebec, Canada, in the 1981-1994 period, Dürr, (1997), established that voluntary culling of cows due to low production, age, constitution, is decreasing more rapidly, while forced (involuntary) culling is increasing, and that according to Fetrow et al., (2006), this has to be controlled and gradually decrease. Pinedo et al., (2010), established that low production and mastitis, as reasons for planned culling, had a 2.5 fold lower share in culling in relation to reproductive problems and injuries. Stojić et al., (2012) established that culling due to leg and hoof problems was more dominant than culling for reasons of selection $(28.4 \%: 23.27 \%)$. The most frequent reasons stated for unplanned i.e. culling not due to selection are reproduction (Ansari-Lari et al., 2012; Stojić et al., 2012; Chiumia, 2011; Pinedo et al., 2010; Fetrow et al., 2006; Seegers et al. 1998 and Allaire et al., 1976), followed by mastitis (Chiumia, 2011 and Fetrow et al., 2006), and leg and hoof diseases (Stojić et al., 2012; Chiumia, 2011 and Fetrow et al., 2006). The causes of culling of first calving heifers on farms were also studied by Novaković et al. (2009) and Petrović M.D. et al. (2004).

For first calving cows, it was established that first calving cows that became pregnant later are culled earlier, due to a higher risk of low production, as well as cows with a weaker expression of characteristics of type (Dürr, 1997). In the overall structure of culled cows, first calving cows accounted for 1/5 (Pinedo et al., 2010 and Maher et al., 2008) to 1/3 (Stojić et al., 2012 and Chiumia, 2011). 
The most frequent reasons for culling were selection and low production (20$29.2 \%$ ), followed by reproductive problems (13-27\%) (Stojić et al., 2012; Seegers et al., 1998 and Allaire et al., (1976). In the tie stall system, 26.7\% of first calving cows were culled due to leg and hoof diseases, and 13.5\% due to metabolic disorders (Stojić et al., 2012). According to research by Dürr, (1997), on the average, first calving cows were culled 215.6 days after calving.

\section{Materials and Methods}

Results for cow culling on seven large farms with a tie stall system located in the northeastern part of the Belgrade region were investigated. In 2011, average of 8837 dairy cows was reared on these farms, with cow numbers by farms of 1080 to 1524 . They realized an average annual production (daily milk production/number of cows x 365 days) of 7587 liters of milk. The analysis of culling first calving cows at different levels of milk production was done on results for culling from two farms each with the highest and the lowest annual production.

On all four farms, cows are reared in a tie stall system in semi-open barns (closed during the winter with bales of hay, during the summer acting as overhangs, with only a minority of barns that are fully enclosed), housing 120-130 cows. Cows are milked using machines and each barn has a milk line, vacuum line and its own lacto-freeze. Cows are grouped by production and fed mixed meals with individual addition of minor quantities of concentrated feeds. In essence, meals consist of alfalfa hay, alfalfa haylage, whole plant maize silage, complete concentrate mixtures, soy meal, molasses and other additions.

According to reasons for culling, all culled animals were divided into 8 groups, while according to the time of culling they were divided into two groups: up to 100 and over 100 days. Data was analyzed using standard mathematicalstatistical procedures.

\section{Results and Discussion}

The two farms with the highest milk production had an annual production per cow of 8175 liters i.e. 8061 liters, while the two farms with the lowest production productions of 7013 liters and 7321 liters (Table 1). On all farms, rearing conditions were almost identical (facilities, milking equipment), the same bulls were used for artificial insemination, the same operative meals and complete concentrate mixtures were used and the conditions for production of roughages were the same. For this reason, it can be said that to the most extent, differences in production, are in fact a consequence of farm management. 
Table 1. Annual milk production per cow on the observed farms

\begin{tabular}{|l|c|c|c|c|c|}
\hline \multirow{2}{*}{ Level of production } & \multirow{2}{*}{ Farms } & \multicolumn{4}{|c|}{ Annual Production } \\
\cline { 3 - 6 } & & ANC & MILK & Fat & Prot \\
\hline \multirow{2}{*}{ High } & H1 & 1524 & 8175 & 3.49 & 3.31 \\
\cline { 2 - 6 } & H2 & 1106 & 8061 & 3.31 & 3.29 \\
\hline \multirow{2}{*}{ Low } & L1 & 1345 & 7013 & 3.33 & 3.30 \\
\cline { 2 - 6 } & L2 & 1080 & 7321 & 3.33 & 3.29 \\
\hline Average of 7 farms & 8837 & 7587 & 3.36 & 3.29 \\
\hline
\end{tabular}

Abbreviations:

ANC - Average number of cows; MILK - Annual milk production per cow, kg; Fat - Average fat content, $\%$; Prot - Average protein content, $\%$

Research results indicate that on farms with a high level of production, the share of culled first calving cows in total culling was $4.5 \%$ lower, amounting to $25.9 \%$ (Table 2). When the structure of culling is investigated relevant to the basic reasons for culling, it can be established that farms with better production have $5.6 \%$ more culling of first calving cows for economic reasons (ER) and $0.7 \%$ more because of forced slaughter (FS), i.e. of the total number of culled first calving cows, $7 \%$ less died (D). It is to be expected that the number of cows culled as a consequence of death and forced slaughter must be reduced, if we strive for higher milk production, all the more so, because the economic effect is also better if more cows are culled for economic reasons.

Table 2. Number of culled first calving cows by primal reasons of culling

\begin{tabular}{|c|c|c|c|c|c|c|}
\hline \multirow{2}{*}{$\begin{array}{c}\text { Level of } \\
\text { production }\end{array}$} & Farms & \multirow{2}{*}{ TNCC } & \multirow{2}{*}{ NCFCC } & \multicolumn{3}{|c|}{ Primal reasons of culling } \\
\cline { 5 - 7 } & & & & D & FS & ER \\
\hline \multirow{3}{*}{ High } & H1 & 528 & $136(25.8 \%)$ & $17(12.5 \%)$ & $3(2.2 \%)$ & $116(85.3 \%)$ \\
\cline { 2 - 7 } & $\mathrm{H} 2$ & 422 & $110(26.1 \%)$ & $22(20.0 \%)$ & $3(2.7 \%)$ & $85(77.3 \%)$ \\
\cline { 2 - 7 } & H1+H2 & 950 & $246(25.9 \%)$ & $39(15.9 \%)$ & $6(2.4 \%)$ & $201(81.7 \%)$ \\
\hline \multirow{3}{*}{ Low } & L1 & 434 & $119(27.4 \%)$ & $33(27.7 \%)$ & $7(5.9 \%)$ & $79(66.4 \%)$ \\
\cline { 2 - 7 } & L2 & 391 & $132(33.8 \%)$ & $19(14.4 \%)$ & $1(0.8 \%)$ & $112(84.8 \%)$ \\
\cline { 2 - 7 } & L1+L2 & 825 & $251(30.4 \%)$ & $52(20.7 \%)$ & $8(3.2)$ & $191(76.1 \%)$ \\
\hline
\end{tabular}

Abbreviations: $\quad$ TNCC - Total number of culled cows; NCFCC - Number of culled first calving cows; D - Death; FS - Forced slaughter; ER - Sale for economic reasons

Similar results for culling of first calving cows in relation to the total number of cows were established by Stojić et al., (2012); Chiumia, (2011) and Seegers et al.,( 1998), while considerably lower results were established by Pinedo et al., (2010) and Maher et al., (2008). 
Table 3. Reasons of culling on farms with different levels of production

\begin{tabular}{|c|c|c|c|c|c|c|c|c|c|c|c|c|}
\hline \multirow[t]{2}{*}{ Reasons of culling } & \multicolumn{2}{|c|}{ Farm H1 } & \multicolumn{2}{|c|}{ Farm H2 } & \multicolumn{2}{|c|}{$\begin{array}{c}\text { High } \\
\text { production } \\
\text { level } \\
(\mathrm{H} 1+\mathrm{H} 2) \\
\end{array}$} & \multicolumn{2}{|c|}{ Farm L1 } & \multicolumn{2}{|c|}{ Farm L2 } & \multicolumn{2}{|c|}{$\begin{array}{c}\text { Low } \\
\text { production } \\
\text { level } \\
(\mathrm{L} 1+\mathrm{L} 2)\end{array}$} \\
\hline & $\mathrm{n}$ & $\%$ & $\mathrm{n}$ & $\%$ & $\mathrm{n}$ & $\%$ & $\mathrm{n}$ & $\%$ & $\mathrm{n}$ & $\%$ & $\mathrm{n}$ & $\%$ \\
\hline Reproductive diseases & 40 & 29.4 & 9 & 8.2 & 49 & 19.9 & 1 & 0.8 & 4 & 3.0 & 5 & 2.0 \\
\hline $\begin{array}{l}\text { Difficult calving and } \\
\text { abortion }\end{array}$ & 4 & 2.9 & 3 & 2.7 & 7 & 2.8 & 1 & 0.8 & 4 & 3.0 & 5 & 2.0 \\
\hline Metabolic disorders & 12 & 8.8 & 15 & 13.6 & 27 & 11.0 & 29 & 24.4 & 13 & 9.8 & 42 & 16.7 \\
\hline $\begin{array}{l}\text { Diseases of legs and } \\
\text { hooves }\end{array}$ & 15 & 11.0 & 65 & 59.1 & 80 & 32.5 & 15 & 12.6 & 41 & 31.1 & 56 & 22.3 \\
\hline Mastitis & 19 & 14.0 & 2 & 1.8 & 21 & 8.5 & 1 & 0.8 & 0 & 0.0 & 1 & 0.4 \\
\hline Udder damage & 9 & 6.6 & 0 & 0.0 & 9 & 3.7 & 0 & 0.0 & 0 & 0.0 & 0 & 0.0 \\
\hline Other diseases & 14 & 10.3 & 13 & 11.8 & 27 & 11.0 & 21 & 17.6 & 9 & 6.8 & 30 & 12.0 \\
\hline Selection reasons & 23 & 16.9 & 3 & 2.7 & 26 & 10.6 & 51 & 42.9 & 61 & 46.2 & 112 & 44.6 \\
\hline
\end{tabular}

Table 3 shows that on farms with better milk production first calving cows were dominantly culled due to leg and hoof diseases (32.5\%), followed by reproduction problems $(19.9 \%)$, metabolic disorders (11\%), as well as for selection reasons $(10.6 \%)$. On farms with lower production, dominant reasons for culling were selection (44.6\%), leg diseases (22.3\%), and metabolic disorders (16.7\%).

Table 4. Reasons of culling on farms with different levels of production by duration of lactation

\begin{tabular}{|c|c|c|c|c|c|c|c|c|}
\hline \multirow{3}{*}{ Reasons of culling } & \multicolumn{4}{|c|}{$\begin{array}{l}\text { High production level } \\
(\mathrm{H} 1+\mathrm{H} 2)\end{array}$} & \multicolumn{4}{|c|}{$\begin{array}{c}\text { Low production level } \\
(\mathrm{L} 1+\mathrm{L} 2)\end{array}$} \\
\hline & \multicolumn{2}{|c|}{$\begin{array}{c}\leq 100 \text { days in } \\
\text { lactation }\end{array}$} & \multicolumn{2}{|c|}{$\begin{array}{c}\geq 101 \text { days in } \\
\text { lactation }\end{array}$} & \multicolumn{2}{|c|}{$\begin{array}{l}\leq 100 \text { days } \\
\text { in lactation }\end{array}$} & \multicolumn{2}{|c|}{$\begin{array}{l}\geq 101 \text { days } \\
\text { in lactation }\end{array}$} \\
\hline & $\mathrm{n}$ & $\%$ & $\mathrm{n}$ & $\%$ & $\mathrm{n}$ & $\%$ & $\mathrm{n}$ & $\%$ \\
\hline Reproductive diseases & 5 & 5.6 & 44 & 28.0 & 0 & 0.0 & 5 & 3.5 \\
\hline Difficult calving and abortion & 2 & 2.2 & 5 & 3.2 & 5 & 4.6 & 0 & 0.0 \\
\hline Metabolic disorders & 19 & 21.3 & 8 & 5.1 & 31 & 28.4 & 11 & 7.7 \\
\hline Diseases of legs and hooves & 30 & 33.7 & 50 & 31.8 & 30 & 27.5 & 26 & 18.3 \\
\hline Mastitis & 9 & 10.1 & 12 & 7.6 & 1 & 0.9 & 0 & 0.0 \\
\hline Udder damage & 2 & 2.2 & 7 & 4.5 & 0 & 0.0 & 0 & 0.0 \\
\hline Other diseases & 11 & 12.4 & 16 & 10.2 & 18 & 16.5 & 12 & 8.5 \\
\hline Selection reasons & 11 & 12.4 & 15 & 9.6 & 24 & 22.0 & 88 & 62.0 \\
\hline
\end{tabular}

In the first 100 days post calving (Table 4), on farms with higher milk production most first calving cows were culled die to leg and hoof problems (33.7\%), metabolic disorders (21.3\%) and mastitis (10.1\%). 12.4\% first calving cows were culled because of selection. The significance of leg and hoof diseases remained almost at the same level for culling after 100 days post calving $(31.8 \%)$, 
however the number of cows culled due to reproduction (28\%) significantly increased.

On farms with a lower level of production, during the first 100 days, most first calving cows were culled due to metabolic disorders $(28.4 \%)$, which are in fact a problem of inadequate nutrition, with nutrition being the most important key to good management. This was followed by leg and hoof problems $(27.5 \%)$, and culling due to selection (22\%). As for culling after 100 days of lactation, culling due to leg and hoof diseases $(18.3 \%)$, was significantly reduced, but culling because of selection almost tripled $(62 \%)$. It is very difficult to provide a realistic explanation for this phenomenon, all the more so since reproductive problems are not dominant in the later phase of lactation, and leg and hoof problems also decrease.

Table 5. Longevity of culled first calving cows on farms with different levels of production

\begin{tabular}{|c|c|c|c|c|c|c|c|c|}
\hline \multirow{2}{*}{ Items } & \multicolumn{4}{|c|}{$\begin{array}{l}\text { High production level } \\
(\mathrm{H} 1+\mathrm{H} 2)\end{array}$} & \multicolumn{4}{|c|}{$\begin{array}{c}\text { Low production level } \\
(\mathrm{L} 1+\mathrm{L} 2)\end{array}$} \\
\hline & $\mathrm{n}$ & $\mathrm{x}$ & SD & $\mathrm{CV}$ & $\mathrm{n}$ & $\mathrm{x}$ & SD & $\mathrm{CV}$ \\
\hline Days in milking & 246 & 248.13 & 197.83 & 79.73 & 251 & 251.42 & 233.40 & 92.83 \\
\hline $\begin{array}{l}\text { Milk production per } \\
\text { milking day, kg }\end{array}$ & 246 & 16.91 & 8.67 & 51.29 & 250 & 15.55 & 8.95 & 57.55 \\
\hline $\begin{array}{l}\text { Milk production per day } \\
\text { of life, } \mathrm{kg}\end{array}$ & 246 & 4.49 & 3.57 & 79.48 & 251 & 3.77 & 3.28 & 87.12 \\
\hline
\end{tabular}

Differences for culling due to selection can maybe be explained by differences in production between first calving cows (Table 5), although they are not high. Maybe the sequence of significance of the diagnosis stated as the reason of culling is more important for this phenomenon, because it depends on management. For this reason the system for making final diagnoses for cow culling should be unified. Thus, farms could be compared more easily, but existing problems in production could also be better perceived.

Considerably lower values for the culling of cows due to leg and foot diseases were established by Stojić et al., (2012); Chiumia, (2011) and Fetrow et al. (2006), as well as for total culling and culling of first calving cows. Other authors mainly established higher numbers of culling, both total and of first calving cows, resulting from reproductive diseases (Ansari-Lari et al., 2012; Chiumia, 2011; Fetrow et al., 2006, Seegers et al., 1998 and Allaire et al., 1976).

\section{Conclusion}

After a comparison of results for culling of first calving cows on farms with different levels of production in 2011 it can be said that there were differences 
for the numbers of culled cows, but also for reasons for culling. On farms with higher levels of production, the share of first calving cows in total culling was $25.9 \%$, or $4.5 \%$ less than on farms with lower levels of production, i.e. there were $4.8 \%$ less deaths and $0.7 \%$ less forced slaughter among first calving cows, while $5.6 \%$ more first calving cows were culled for economic reasons.

For both levels of production, dominant reasons for culling were leg and hoof diseases (more pronounced on farms with higher production), and metabolic disorders (more dominant on farms with lower production). Reproduction was a more dominant problem on farms with higher milk production. The most dominant reason for culling on farms with low production is culling due to selection (44.6\%).

In early lactation of first calving cows and on farms with higher and with lower production, the dominant reasons for culling are leg and hoof problems and metabolic disorders (total 55\% i.e. 55.9\%). When investigating reasons for culling first calving cows after 100 days of lactation, on farms with high production, the importance of leg and hoof diseases remained almost unchanged, but culling due to reproduction increased to $28 \%$. On farms with lower production, culling due to leg and hoof diseases is considerably lower after 100 days of lactation, but the number of first calving cows culled due to selection reasons is tripled (62\%).

In the coming period, it would be desirable to unify the system for making final diagnoses for culling cows.

\title{
Uzroci izlučenja prvotelki na farmama sa različitim nivoom proizvodnje
}

\author{
P. Stojić, R. Beskorovajni, V. Pantelić, Ž. Novaković, S. Bojković Kovačević, \\ D. Stanojević
}

\section{Rezime}

Opšte je poznato da menadžment u najvećoj meri utiče na rezultate $u$ govedarskoj proizvodnji, a izlučenja krava su vrlo kvalitetan pokazatelj uspešnosti upravljanja farmama. Poredeći rezultate izlučenja prvotelki na farmama sa različitim nivoom proizvodnje u toku 2011. god. ustanovljene su razlike i u broju izlučenih grla, ali i u razlozima izlučenja. $\mathrm{Na}$ farmama sa višim nivoom proizvodnje učešce prvotelki u ukupnim izlučenjima bilo je $25.9 \%$ što je za $4.5 \%$ manje nego na farmama sa nižim nivoom proizvodnje, odnosno uginulo je za 4,8\% manje i prinudno je zaklano za $0,7 \%$ manje prvotelki, a iz ekonomskih razloga izlučeno za $5.6 \%$ prvotelki više. 
Na oba nivoa proizvodnje dominantni razlozi izlučenja su bili oboljenja nogu i papaka što se može dovesti u vezu sa vezanim sistemom držanja (izraženije na farmama sa većom proizvodnjom) i metabolički poremećaji (dominantnije izraženi na farmama sa nižom proizvodnjom). Reprodukcija je bila znatniji problem na farmama sa većom proizvodnjom mleka, odnosno selekcijska izlučenja na farmama sa nižom proizvodnjom. U ranoj laktaciji prvotelki, bez obzira na nivo proizvodnje, na farmama kao razlozi izlučenja dominiraju problemi sa nogama i papcima i metabolički poremečaji (ukupno 55\% tj. 55.9\%). Kada se posmatraju razlozi izlučenja prvotelki nakon 100 dana laktacije, na farmama sa visokom proizvodnjom značaj obolenja nogu i papaka je gotovo nepromenjen, ali izlučenja usled reprodukcije rastu na $28 \%$. Na farmama sa nižom proizvodnjom, izlučenja usled oboljenja nogu i papaka su znatno smanjena nakon 100 dana laktacije, ali je zato utrostručen broj izlučenih iz selekcijskih razloga (62\%).

\section{References}

ALLAIRE F.R., STERWERF H.E., LUDWICK T.M. (1976): Variations in Removal Reasons and Culling Rates with Age for Dairy Females. J. Dairy Sci., 60:254-267

ANSARI-LARI M., MOHEBBI-FANI M., ROWSHAN-GHASRODASHTI A. (2012): Causes of culling in dairy cows and its relation to age at culling and interval from calving in Shiraz, Southern Iran. Veterinary Research Forum, 3 (4): 233 - 237 BEAUDEAU F., SEEGERS H., DUCROCQ V., FOURICHON C., BAREILLE N. (2000): Effect of health disorders on culling in dairy cows: A review and a critical discussion. Ann. Zootech. 49: 293-311

BEAUDEAU F., HENKEN A., FOURICHON C., FRANKENA K., SEEGERS H. (1993): Associations between health disorders and culling of dairy cows: A review. Livestock Production Science, 35 (3): 213-236

CHIUMIA D. (2011): Vulnerability in Holstein-Friesian dairy cows: Risk factors for culling and effect of temperament on oestrus. M. Sc. thesis. The University of Edinburgh

DJEDOVIĆ R., LATINOVIĆ D., STOJIĆ P., BOGDANOVIĆ V., TRIFUNOVIĆ G. (2002): Naslednost osobina mlečnosti krava u zavisnosti od nivoa proizvodnje. Biotehnologija u stočarstvu, 18 (5-6):17-22

DÜRR J.W. (1997): Genetic and phenotypic studies on culling in quebec holstein cows. Ph.D. thesis. Department of Animal Science, McGill University, Montreal, Canada

FETROW J., NORDLUND K.V., NORMAN H.D. (2006): Invited Review: Culling: Nomenclature, Definitions, and Recommendations. J. Dairy Sci. 89:18961905

MAHER P., GOOD M., MORE S.J. (2008): Trends in cow numbers and culling 
rate in the Irish cattle population, 2003 to 2006. Irish Veterinary Journal, 61 (7): 455-463

MOUSSAVI A.H. (2008): Days in milk at culling Holstein dairy cows. J. Anim. Vet. Adv., 7 (1): 89-93

NIENARTOWICZ-ZDROJEWSKA ANNA, DYMARSKI IRENEUSZ, SOBEK Z., WOLC ANNA (2009): Culling reasons as related to lifetime dairy performance in Polish Friesian (Black-and-White) cows on Pawłowice farm in the years 19092006. Animal Science Papers and Reports, 27 (3): 173-180

NOVAKOVIĆ Ž., ALEKSIĆ S., SRETENOVIĆ LJ., PETROVIĆ M.M., PANTELIĆ V., OSTOJIĆ-ANDRIĆ D. (2009): Longevity of high-yielding cows. Biotechnology in Animal Husbandry 25 (5-6): 645-654

PETROVIĆ M.D., SKALICKI Z., GUTIĆ M., BOGDANOVIĆ V. (2004): Uticaj paragenetskih faktora na osobine dugovečnosti krava simentalske rase. Biotechnology in Animal Husbandry, 20(3-4):23-29

PINEDO P.J., DE VRIES A, WEBB D.W. (2010): Dynamics of culling risk with disposal codes reported by Dairy Herd Improvement dairy herds. J. Dairy Sci. 93: 2250-2261

SEEGERS H., BEAUDEAU F., FOURICHON C., BAREILLE N. (1998): Reasons for culling in French Holstein cows. Preventive Veterinary Medicine, 36:257-271 STOJIĆ P., BOJKOVIĆ-KOVAČEVIĆ S., BESKOROVAJNI R., JEREMIC I., PANTELIĆ V. (2012): Causes of cow culling in the tie stall system. Biotechnology in Animal Husbandry 28 (4): 697-704

STOJIĆ P., DJEDOVIĆ RADICA, LATINOVIĆ D., NIKOLIĆ R. (2000): Heritabilnost osobina mlečnosti u različitim uslovima proizvodnje mleka goveda. Journal of Scientific Agricultural Research, 61 (3): 15-22 